\title{
CONVENTION ON CIVIL ASPECTS OF INTERNATIONAL CHILD ABDUCTION: AN ANALYSIS OF THE EXCEPTION ARTICLES 12 AND 13 “B” IN THE BRAZILIAN LEGAL SYSTEM
}

\section{CONVENÇÃO SOBRE OS ASPECTOS CIVIS DO SEQUESTRO INTERNACIONAL DE CRIANÇAS: UMA ANÁLISE DOS ARTIGOS EXCEÇÕES 12 E 13 “B” NO SISTEMA BRASILEIRO}

\section{LETICIA VIRGINIA LEIDENS}

Doutora em Direito pela Universidade Gama Filho (2015) com período de pesquisa na Università di Salerno e Pisa, Itália. Especialista em Diritto Comparato pela Università Degli Studi di Salerno (2011), com bolsa de estudos do Ministero Degli Affari Esteri Italiano e della Cooperazione Internazionale. Mestre em Direito pela Universidade de Santa Cruz do Sul (2009). Graduada em Ciências Jurídicas e Sociais pela Universidade de Passo Fundo (2007). Professora Adjunta do Departamento de Direito de Macaé, da Universidade Federal Fluminense - UFF, vinculada ao curso de Graduação em Direito. Tem experiência na área de Direito, com ênfase em Direitos Especiais - Direito Internacional e Direitos Humanos. E-mail: lleidens@gmail.com; ORCID ID: https://orcid.org/0000-0002-3185-6624.

\section{ABSTRACT}

This is a study of the 1980 Convention on Civil Aspects of International Child Abduction, an instrument of protection of children in the international sphere, specifically when they are subjected to the change of usual residence, resulting from the act of retention or illegal transfer of the parent. The issues include the verification of the contents of two conventional articles, which lack subjectivity in the normative plan and allow the judge to dismiss the order of return of the child to the State of usual 
residence. The option for methodological verification consists of the case law verification of the topic, more thoroughly with regard as to how they are materialized in Brazilian practice.

KEYWORDS: Application; Exception articles; Hague Convention; Interpretation; Jurisprudence.

\section{RESUMO}

Trata-se de um estudo da Convenção sobre Aspectos Civis do Sequestro Internacional de Crianças de 1980, instrumento de proteção da criança no plano internacional, especificamente quando esta se encontra submetida à mudança de residência habitual, decorrente do ato de retenção ou transferência ilícita do genitor(a). A problemática perpassa na verificação do teor de dois artigos convencionais, os quais carecem de objetividade no plano normativo e permitem que o julgador afaste a ordem de retorno da criança ao Estado de residência habitual. A opção metodológica verificativa consiste na averiguação jurisprudencial do tema, detidamente em como eles se materializam na prática brasileira.

PALAVRAS-CHAVE: Aplicação; Artigos exceções; Convenção da Haia; Interpretação; Jurisprudência.

\section{INTRODUCTION}

The occurrence of mixed unions between people of different nationalities or domiciles is connected to a social reality, giving rise to several consequences, if a break-up occurs. It is further worsened when such relationships bear children. In order to meet the social demand, the international law presents legal instruments in order to protect and regulate such issues. Among the legislative instruments, the 1980 Convention on civil aspects of international child abduction is concerned with the 
protection of the child, when it is found that international child abduction is taking place. In this regard, it expressly has a general purpose, consisting of the immediate order of the return of the child to the State of usual residence, aiming at inhibiting the harmful effects of such practice. Alongside such general purpose, normative situations are also presented, which may dismiss the order of return and consequently allow the judge to state that the child is to remain in the abductor State.

Thus, due to the normative reality of two great possibilities, which consequently changes the usual residence of the child to determine the exercise of custody and/or visit, it is required to compare them in a systematic manner, in order to extract limits and possibilities in the interpretation and conventional application, grounded on the Principle of the child's interest. Also, upon finding that the exception standards present circumstances that are open and not objective, the first option is to check, within the case law, how the matter has been developed and applied.

\section{THE CONVENTIONAL PURPOSES AND THE EXCEPTION ARTICLES: REQUIRED INTERACTION}

The 1980 Convention on the civil aspects of international child abduction focused on making clear, in its initial articles, the outline of its purposes, taking into account that, throughout its normative framework, the conventional legislator sets forth the possibility of making exceptions thereto, due to the application of the exception articles set out therein.

Thus, it establishes in its article 1, "a", that the conventional purpose is related to the immediate return of the illegally taken or transferred child to the State of usual residence, consolidating the pursuit of the status quo ante of the illegal situation. Furthermore, article 1, "b", points out that it is aimed at "causing compliance with the rights of custody and visit existing in one Contracting State in the other Contracting States". In any case, from such legislative orientation, it may be said that the judge, upon facing a case that involves the application of the Convention, must consider such first intention of the international document, that is, to order the return of the child to 
the State of usual residence. It is justified from the observance of the grounds of the Convention (MAURIQUE, 2008, p. 25), based on the compliance with the Principle of the Child's Interest, as well as on respecting the demonstration of the element of connection, which the Convention itself points out, of the usual residence, to settle the underlying matter of the custody. Thus, it must be stated that the Convention tends to direct such analysis to the natural judge, since he or she is closer to the family reality of both parents.

However, one shall evidently not imagine that all cases that involve the illegal international abduction have as normative response the immediate return of the child to his/her State of usual residence. So much so that the Convention was not concerned with safeguarding the normative situations where the order of return is not in the child's interest, since it would be more harmful to him/her than remaining in the abductor country. Taking such overview into account, the Convention sets forth normative circumstances in articles $(12,13$, and 20) that make an exception to the order of return of the child. It must be stressed that such articles are provided in the Convention in chapter three, related to heading "return of the child". Under such logic, it is understood that the reason for such insertion is just to make it clear to the interpreter that it is an exceptional application, with the enforcer of the Law having, first and foremost, to comply with the conventional general rule. On the other hand, the Convention makes it clear that the application thereof must be argued with the supporting evidence that shows and substantiates the presence of circumstances against the return of the child for purposes of his/her best interests.

Thus, the judge must consider that the enforceability of such articles is restricted, since it is contrary to the first purpose of the Convention, which is the immediate return of the child illegally abducted. Under such aegis, it is attempted to preserve the essence of the Convention and not to subvert its system with the prevalence of exceptions. The exceptions considered as safety valves seem to grant to the document the flexibility and discretion to avoid that the application of the conventional rules brings damages to the child (MARTINS, 2013, p.63). However, such trend is not confirmed in practice, since in an analysis of the case law regarding the treatment granted to said articles by the competent authorities it was demonstrated 
that the application thereof is a recurring factor in the analyzed cases of the Contracting States, and also often used as grounds for the request made by the abductor parent.

It must be observed that the dismissal of the order of return by the enforcer of the Convention entails a "benefit" to the abductor parent, since it "chose" the jurisdiction and the governing law applicable to the resolution of the conflict, often favorable thereto. The perpetuation of such stance without the Contracting States committing to the conventional guidelines may contribute to encouraging the practice of abduction, since in a certain way the illegal situation was not reverted to the status quo ante. Therefore, considering that the situations set out in the exception articles of the Convention dismiss the "immediate" return of the child, it is understood that, to achieve the conventional essence (grounds, objectives, and purposes), the competent authority must assess the complexity of the question, as a counterpoint (general rule $x$ exceptions) and, with regard to the enforceability of the latter, carefully observe the objective criteria emanated thereby, in parallel with the systematic of the provisions of the Convention. Such scenario allows us to distinguish two great normative categories in the Convention: general rule and exceptions for the configuration of the child's destiny, supported by the composition of the child's balance between the return to the status quo ante or staying in the new country.

Therefore, from the description of the normative system of the Convention, it is possible to assess that both possibilities are supported by the norms and case law based on the child's interest. It is important to consider that, to achieve the goal of the Convention, the interpretation and enforceability of the general rule or of the exception articles shall be as instructed in the Convention, in order not to exceed the limits defined thereby, since it is a matter that involves social impact, which aims to avoid or minimize the damages of family rupture, as well as child abduction, sale, and international traffic. In any event, even though the interpretation and application thereof is complex, it must be considered that the contents of the exception articles lack objectivity, since the content of the circumstances was not defined by the legislator that enacted the Convention. Thus, the analysis of the investigation is restricted to article 12, regarding the normative circumstance of the adaptation of the child to the new environment, as well as article 13, "b", consisting of the existence of a serious risk of 
the child, upon his/her return, being subject to physical or psychological hazards or, in any manner, being in an unbearable situation.

Therefore, considering they are exceptional circumstances of the Convention, which allow the judge to dismiss the order of return of the child to the State of usual residence, we must point out how such normative hypotheses are presented in the application plan. That is because it is noted that normatively there is no indication of what the child's integration to the new environment means, as well as the physical or psychological hazard, or also an unbearable situation.

Thus, we suppose that the appraisal of the matter, from a case law point of view, will provide different ways of factually viewing such exceptional circumstances, entailing a content cannot be verified in the norms to, connected among themselves, form interpretative parameters regarding the circumstances presented in the Convention.

\section{ANALYSIS OF THE BRAZILIAN CASE LAW: CERTAIN PREMISES ON ARTICLES 12 AND 13 "B" OF THE CONVENTION}

Firstly, we must stress that the guidelines set forth in the Convention regarding the statement that the articles that regulate the exceptions to the return of the child to the State of usual residence shall be restrictively applied (PEREZ-VERAS, 1982, p. 78). Such line of thought shall be assumed by the judge, under penalty of deceiving the very meaning provided thereby, which causes its timely verification, arising from the hermeneutic rule of the Vienna Convention on the Law of Treaties:

The mistaken management - especially, excessively broad - of the cases of exception will lead, at the most, to the non-enforceability of the treaty situation which, in addition to being contrary to the best interests of the child, may generate consequences related to the international responsibility of the non-complying State (...). The fundamental benchmarks of the Hague Convention of 1980 are the unanimous conviction of the phenomenon of the illegal abduction of a child, and the conviction that the best method to fight them, on an international basis, consists of the recognition of legal consequences. In practice, the Member States of the covenant must be convinced that, despite their differences, they participate in a sole legal 
community, where the authorities of each country recognize that it is those (authorities) of the place of usual residence of the child that, in principle, are better equipped to decide, with justice, on the merits of the right of custody and visits. (MARTINS, 2013, p. 115-16).

We hereby quote the provisions in article 31 of the said Convention, which state that "a treaty shall be interpreted in good faith according to the common meaning attributed to the terms of the treaty in its context in light of its objective and purpose." Moreover, it must be highlighted that in the main clause of such standards there is the mention of the expression "to prove". It means to say that the enforceability condition of the exception articles takes effect upon evidence of the situation listed by the standard, by the parent that perpetrates the illegal abduction. Such criterion dismisses the possibility the judge deems the mere allegations of normative incidence to be valid. ${ }^{1}$ As stated in the civil procedure, the burden of proof lies with the party that makes the allegation.

Regarding the case of incidence of article 12, related to the integration of the child into the new environment, the legislator that drafted the Convention set forth that there is normative assumption that the integration of the child in the new environment may not materialize in a term shorter than 12 months, since the Convention itself instructs the immediate return of the child, upon such requirement not being complied with. That is, such establishment of a time period authorizes the Court to work with the perspective that the integration of the child in the new social environment is conditioned to over 12 months, not being required to consider the adaptability in question before such lapse. Therefore, the limitation to the application of such obstacle is yet another factor that is compliant with the purpose of the Convention set forth in article 1 thereof, also because there is a provision of the term "immediate" next to return, in the main clause of article 12 of the Convention. We conclude that the term set forth by the rule may entail several effects to the particular case.

Regarding the situation itself, brought by article 12 of the Convention, integration of the child in the new environment, it is understood that it may be

\footnotetext{
${ }^{1}$ Such understanding is also found in Eliza Pérez-Vera's report and in the preparatory works of the
} Hague Conference. 
understood as a family reality, in a broad sense, which comprehends the social and cultural elements, which may guarantee the psychological and physical development of the child, to such an extent that suggests that the stay in the new environment is more advantageous than the return. In any event, the scope is to avoid that he/she is abruptly taken from his/her environment and inserted into another again, and that it constitutes an additional trauma. However, even if it is possible to glimpse certain perspectives of normative enforceability, its openness is clear, since it does not point out aspects to be considered for its implementation. Upon the foregoing, the judge is responsible for assessing, on a case-by-case basis, through the use of the elements submitted by the parties to the case, the meaning of the body of evidence that will prevail for the decision. It is intended to extract from the case law criteria that define the integration of the child in the new environment, taking into account the lack of objectivity of such standard. Thus, it is believed that the case law research may assist in such limitation, and which may serve as objective parameters for assessment of such express contents in a normative manner.

The time line examined in relation to article 12 was restricted to the cases judged between 2006 and 2016, available in the internal case law research of the Brazilian system of the federal courts. It must be stressed that the application of the Convention is held in camera, considered to be the element that prevented and limited the public access of cases that involve the matter. We opted for analyzing only the cases that decided for the dismissal of the order of return of the child, on the grounds of the article in question, in this case article 12, and which used them as sole grounds in the application of the law. That is because we believed that, from an analysis of cases with the same outlines and limitations, it is methodologically possible to extract, in a coherent manner, the answers of the courts addressing the theme, in a methodologically organized line. In this regard, the qualitative analysis appraised 7 (seven) cases in the pre-determined molds, from the Federal Regional Courts (TRFs) of the: (TRF 1 Region, AP oㅜ 00063872120104013814, 2016a), (TRF 1 Region, AP oㅡ $00003352220084013800,2016 \mathrm{~b}$ ) (TRF 1 Region, APREENEC $\mathrm{n}^{-}$ 00029409520054014300, 2011a) (TRF 1 Region, AP o 00192869820074013800, 
2010); (TRF 2 Region, AP o 200351010184945, 2011b) (TRF 2 Region, AP oo 200451010222719, 2011c); (TRF 3 Region, AP no 00027772320014036104, 2012).

From the collection of the elements used in said case law, we note that only case no. AP 00027772320014036104 , from the TRF of the $3^{\text {rd }}$ Region, considered the assumption of enforceability set forth in the main clause of article 12 of the Convention as a methodological factor of assessment, before handling the exception article itself. We must mention that the Court appraised whether less than one year had elapsed between the date of the undue transfer or retention and the start date of the case before the judicial or administrative authority of the Contracting State, for the enforceability of the integration of the child in the new country. Thus, in such event, the Court understood that, given the fact that the period set out in the standard had elapsed, it was assessed as indicative to point out the adaptation of the child.

In another aspect, regarding the criteria considered usual from a Brazilian perspective, we highlight as essential the opinion of a technical examination submitted in the case records, from the appraisal by a Social Assistant and a Psychologist. Such element of proof, in a general manner, appraised the relationships formed by the child in the new environment, resulting from different origins, which are family, school, social, and affection towards the abductor mother. Such verification was found in the majority of the analyzed cases, except for two, cases no. AP 00027772320014036104 and no. AP 200451010222719, of the Regional Federal Court of the $3^{\text {rd }}$ and $2^{\text {nd }}$ Region, respectively. However, such first case, although it does not mention that the conclusions resulted from the assessment of the expert evidence, the decision mentioned the presence of the relationships highlighted above in the new life of the child. Thus, it may be said that such criterion constitutes an essential factor to check the safety and stability of the child, considered by the cases a condition to ratify the integration into the new environment.

Another recurring criterion in the analyzed cases was the presentation of certificate of school registration of the child, which would mean continuity of the activities interrupted by the illegal abduction of the child, as it is checked in all analyzed cases. It may be said that the mere presentation of this document was deemed by the judges as an element for the assessment of the integration. Moreover, the conditions 
of good health presented by the abducted children were evidenced, considering the preservation of the intellectual and motor development, specifically, in three cases, (AP o 00063872120104013814, 2016a), (AP o 00003352220084013800, 2016b) and (AP $n^{\circ} 00192869820074013800,2010$ ) all of the $1^{\text {st }}$ Region. In the same regard, the environmental conditions were evaluated, such as fixed and own residence, under the terms of two cases (TRF 2 Region, AP № 200351010184945, 2011b) and (TRF 1 Region, AP no 00192869820074013800,2016 ). It may be said that the integration exceeds the mere adaptation to the new environment, since it denotes the child's involvement with the environment, either upon the behavior at school, or in the family development. The integration is presented as a continuous and lasting perception in the new environment, indicia to the contrary having to be absent. The adaptation is bound to the perception of the current life of the child and with the possibility of projecting the continuity of the child's well-being to the present and future.

It was found, based on the criteria pointed out, that the judge starts from an investigation into the child's answer, based on the environmental, social, family, school, and affective stimuli supported thereby. Therefore, it starts off the premise that the relationships created by the child in the new environment and positively answered thereby are showed as the main evaluative parameter, from the analyzed cases, for the enforceability of the prevention to the return, set forth in article 12 of the Convention. Thus, it is believed that such parameters provided by the research serve as preliminary premises to understand the sense in which the exception articles of the Convention are used from a Brazilian point of view, there being no intention to exclude other application possibilities arisen inside the case.

In another sphere, we shall now analyze the normative hypothesis contained in article 13, "b", of the Convention. Such standard specifically refers to the existence of a serious risk of the child, upon his/her return, being subject to physical or psychological hazards, or being in an unbearable situation, upon his/her return to the State of usual residence. That is, the Convention supposes situations that may cause harm to the child. And, once identified, they serve as obstacles legitimated by the standard for the implementation of the status quo ante of the illegal abduction. However, as a rule, the content of the article in question presents hypotheses 
connected to violence. It may be perpetrated against the child or the abductor parent, but its effects must fall upon the child. Another assumption that may be extracted from the standard in question is that the risk must be serious. That is, for the rule to apply, it shall be a significant and expressive risk, no irrelevant situations being considered for such. In any event, as it is understood from the Convention, the mere existence of a serious risk proves to be sufficient for the enforceability of the article. This article presents three situations that shall be considered by the interpreter and enforcer of the standard, to wit: physical hazards, psychological hazards, and unbearable situations. As can be found in the case law, the physical and psychological hazards are connected to situations that involve domestic violence or, as an extreme measure, sexual abuse. Therefore, they are cases that arise from facts lived by the family before the illegal abduction or after its implementation, related to the child individually considered. But regarding the unbearable situation, the doctrine identifies it in universally consolidated and external events, such as war, epidemics or food shortage, which affects any child, not the concrete situation per se (CONTI, 2004, p. 56). In the words of jurist Jacob Dolinger, they must be interpreted from a humanitarian viewpoint, in relation to the child (DOLINGER, 2003, p. 47).

From the case law analysis examined, where the judge strictly applied article 13 , "b" of the Convention, ordering the dismissal of the order of return, 4 (four) cases were studied, from the Courts of the (TRF 1 Region, AP o 00438066120074013400 , 2011d), (TRF 1 Region, APREENEC no 00029409520054014300, 2011a); (TRF 2 Region, AP no 20040201009861-7, 2013), and (TRF 5 Region, AP $n^{\circ}$ $00117314420124058100,2013 \mathrm{~b}$ ), with the same methodological limitations outlined in the verification of the cases set out in article 12 of the Convention. It must be considered that the serious risk was restricted to the idea of violence, either physical or psychological, as expressed in all cases examined. Consequently, it is a criterion intended to dismiss a possible situation applied to the child.

Among the sundry aspects of serious risk, the case law defined as concrete materialization thereof threats directed to the mother by phone, after the illegal abduction, found in two cases (TRF 2 Region, AP o 20040201009861-7, 2013), and (TRF 5 Region, AP № 00117314420124058100, 2013b). Also, it considered the 
aggressions occurred when the family lived together in the State of usual residence of the child. This was ascertained based on the restrictions on proximity between the parents, ordered by the local courts, as pointed out in two cases (TRF 1 Region, AP no $00438066120074013400,2011 \mathrm{~d}$ ) and (TRF 5 Region, AP no $^{-}$ $00117314420124058100,2013 b)$ analyzed. In addition, there were criteria based on forecast of future damages to the child, such as the filing of criminal measures against the mother, which could cause her imprisonment, if the return of the child is ordered.

Thus, it may be said that the concept of violence, due to the fact that it is comprehensive, is applicable in a significant number of hypotheses, being able to be abstractly or concretely assessed, as an actual damage experienced before the illegal abduction, and that, if relived, represents a serious risk to the child's well-being. In most of the cases, the threats were taken before the courts to report to problems already experienced. It is concluded that the harmful practice in question, before the illegal act, is more recurrent than a future threat to the child, although there is a normative provision that states that the serious risk is concretely consolidated with his/her return. In another aspect, the incidence of the violence repeatedly occurred in the cases analyzed, against the abductor mother, and not the child, individually considered, as pointed out in four of the analyzed cases. However, it was noticed that the judge made an interpretative conjecture, assessing that the risk would fall upon the child at his/her return to the country of origin. Also, as an exceptional criterion, the judge considered that the mere allegation surrounding the serious risk, whether physical or psychological, was sufficient to consolidate the hazard described in the rule set forth in article 13, "b", of the Convention, occurred in case (TRF 2 Region, AP no 20040201009861-7, 2013).

Therefore, it is a criterion that is not uniform in the scope of the analyzed cases, but repeatedly assessed based on evidence, and in most times the mere allegation did not suffice for such. Furthermore, there is a line of thought, according to which the violence factor must be solely assessed by expert examination report, being a necessary element. It may result from the mother's testimony or behavioral signs of the child, combined with the memories that he/she presents of the figure of the parent who remained in the State of usual residence, as it was checked in case (TRF 5 
Region, AP no 00117314420124058100, 2013b). Finally, it was determined that the serious risk is a future projection, taken to effect and materialized with the return of the child to the State of usual residence.

With regard to the situation unbearable for the child, the case law bound it to the return to the State of origin. The decisions that pointed out the existence of a serious risk to the child alerted that the return itself would cause an unbearable situation. That is, the return would expose the child to the compromise of his/her wellbeing. From such analysis, the idea of intolerability occurred within the family relationship, reason why such perspective distanced itself from the doctrine, which was based on external factors, such as the case of catastrophes, wars, and revolutions. Consequently, we ponder that the criteria used to apply article 13, "b", of the Convention are grouped in the analyzed cases. The situations are considered typical to materialize the normative statement of the serious physical or psychological risk. They naturally present some variations and differences such as the assessment of the serious risk and of the necessity of actual proof.

On the other hand, the case law adopted well-aligned criteria regarding the serious risk being a future possibility. Such point of view was based on damages already experienced by the child, previously to the abduction, which is a factor of future prevention. In any event, it may be said that the methodology adopted found more similarities than differences, with the enforceability criteria remaining, under such parameter, uniform. In fact, the intention was to explore the treatment of such circumstances in the Brazilian case law scenario, in order to materialize the open perspective proposed by the Convention. In a way, it was possible to extract certain initial premises from the standards that lack objectivity, which match the conventional grounds and purposes.

In any case, the Convention still requires significant deepening, taking into account the several complexities that its normative framework presents. Thus, the elements brought by the Brazilian case law in the establishment of such criteria allow us to reflect on the elements selected to specifically express the integration of the child into the new environment, as well as the physical or psychological risk, or unbearable 
situation, even though it considers them to be general parameters from a Brazilian perspective.

\section{CONCLUSION}

We attempted to outline a general overview of the application of the 1980 Convention on Civil Aspects of International Child Abduction, evidencing the difficulties and complexities entailed by its normative content and compared, especially, in with regard to the interpretation and application process thereof. In any event, it was necessary to define the very provisions of the Convention, regarding the grounds and purposes thereof, as well as the enforceability premises, in order to refer any decision that involves the theme. Thus, it was essential to work with the main points, such as the idea of usual residence, the purpose of indication of the immediate return of the children to the State of usual residence, as well as the exceptions that dismiss such order, based on the principle of interests of the child.

Thus, due to the difficulty entailed by the lack of normative objectivity of the exception articles, since there is no indication of what the adaptation of the child to the new environment consists of, nor the serious risk, either physical or psychological, or even the unbearable situation, the case law environment was essential to build general notions of such circumstances, even if in a limited and partial stance. This occurred with article 12 of the Convention, which dealt with the integration of the child to the new environment. The process of incidence of the analyzed cases occurred from the verification of the criteria that involved the time spent in the new environment and the formation of affective, social, family, and school relationships the child presented in the new country. Even if other criteria that contributed to the final result of the indication of the refusal are showed, they will not prevail according to the general parameters, which are considered to tend to be uniform between them.

The researched case law presented some identifying criteria to conclude for the integration of the child in the new environment, provided that he/she positively answers to the stimuli of assessment of the theme. Such aspects are the exam of the time spent by the child in the new country; the social and family bonds formed in such period; the school inclusion and performance presented; the display of good health of 
the child; the environmental conditions, such as fixed residence or leased residence; the projection around the image of the parent that remained in the State of usual residence. The English version of the 1980 Hague Convention coins the term "new environment". Such term, individually considered, presents a universe of conceptual possibilities, comprehending, for example, the idea of house, school, religious institution and activities, being, therefore, compatible with its predictability and applicability.

In relation to article 13 , "b", of the Convention, for its turn, which referred to the existence of a serious physical or psychological risk for the child, as well as an unbearable situation, it presented a line of thought regarding what the idea of serious risk consists of. In general, it was connected to domestic violence experienced before the configuration of the illegal situation, especially against the mother, but which produced negative effects on the child. The orientation formed consisted of the damages the circumstance of violence would generate to the child, which is a preventive justification for the dismissal of the order of return. It does not ignore other criteria that are classified in the idea of serious physical or psychological risk, since it is treated as a concept open to possibilities, including, for example, the absence of payment of alimony. However, it must be highlighted that the researched case law presented a definition of approach based on the materialization of the domestic violence occurred within the family structure.

Consequently, the investigation explored the Brazilian case law universe of the application of the Convention, thoroughly referring to articles 12 and 13 "b", within the criteria defined by such research, aiming at establishing general notions of how the practical treatment of the material standards has been made. The motivation for such perspective was the ability to appeal the use of the exceptions to the child's return in a preliminary analysis of the case law. Thus, the matter is complex, revisiting the questions throughout the development of the work, under other methodological aspects, being applicable, in order to overcome and improve obstacles arisen from such stance, still in the perspective of the interpretation and application of the Convention and achievement of the maximum protection of the child at an international level. 


\section{REFERENCES}

ARAÚUO, Nadia; VARGAS, Daniela. Comentário ao REsp 1.239.777: o dilema entre a pronta devolução e a dilação probatória na Convenção de Haia sobre os aspectos civis do seqüestro internacional de menores. Revista da Doutrina da 4a Região. Porto Alegre, n. 60, jun. 2014.

ASSOCIAÇÃO PORTUGUESA DE CRIANÇAS DESAPARECIDAS. Um guia para pais e educadores. $2011 . \quad$ Disponível em: <http://www.ester.janz.pt/APCD_Manual_de_Seguranca_Infantil.pdf. Acesso em: 03 out. 2018.

BRASIL. Tribunal Regional Federal (1. Região). Apelação cível $n^{o}$ 00063872120104013814. Relator: Desembargador Federal JIRAIR ARAM MEGUERIAN. DJE: 25/04/2016a, Unânime. Disponível em: https://www2.jf.jus.br/juris/unificada/Resposta. Acesso em: 03 out. 2018.

Apelação cível no 00003352220084013800 . Relator: Desembargador Federal JIRAIR ARAM MEGUERIAN. DJE: 25/04/2016b, Unânime. Disponível em: https://www2.jf.jus.br/juris/unificada/Resposta. Acesso em: 03 out. 2018.

Apelação cível e Remessa Necessária no 00029409520054014300. Relator: Desembargador Federal CARLOS MOREIRA ALVES. DJE: 16/05/2011a, Unânime. Disponível em: https://www2.jf.jus.br/juris/unificada/Resposta. Acesso em: 22 maio 2018.

Apelação cível no 00192869820074013800. Relator: Juiz Federal Convocado DAVID WILSON DE ABREU PARDO. DJE: 16/11/2010, Unânime. Disponível em: https://www2.jf.jus.br/juris/unificada/Resposta. Acesso em: 20 maio 2018.

Apelação cível no 00438066120074013400. Relator: Desembargador Federal JIRAIR ARAM MEGUERIAN. DJE: 29/07/2011d, Unânime. Disponível em: https://www2.jf.jus.br/juris/unificada/Resposta. Acesso em: 18 jun. 2018.

Tribunal Regional Federal (2. Região). Apelação cível no 200351010184945. Relator: Desembargador Federa/BENEDITO GONÇALVES. DJE: 18/04/2011b, Unânime. Disponível em: https://www2.jf.jus.br/juris/unificada/Resposta. Acesso em: 30 out. 2018.

Apelação cível no 200451010222719. Relator: Desembargador Federal BENEDITO GONÇALVES. DJE: 19/05/2011c, Maioria. Disponível em: https://www2.jf.jus.br/juris/unificada/Resposta. Acesso em: 09 set. 2018. 
Apelação cível no 20040201009861-7. Relator: Desembargador Federal GUILHERME CALMON NOGUEIRA DA GAMA, DJE: 14/02/2013, Unânime. Disponível em: https://www2.jf.jus.br/juris/unificada/Resposta. Acesso em: 12 jun. 2018.

Tribunal Regional Federal (3. Região). Apelação cível no 00027772320014036104. Relator: Desembargador Federal ANDRÉ NEKATSCHALOW. DJE: 24/11/2012, Unânime. Disponível em: https://www2.jf.jus.br/juris/unificada/Resposta. Acesso em: 20 nov. 2018.

. Tribunal Regional Federal (5. Região). Apelação cível no $A C$ 00117314420124058100. Relator: Desembargador Federal FRANCISCO CAVALCANTI. DJE: 17/10/2013b, Unânime. Disponível em: https://www2.jf.jus.br/juris/unificada/Resposta. Acesso em: 12 set. 2018.

BUGETTI. Custodia e affidamento nella sottrazione internazionale di minori. In: Rivista di Famiglia e Diritto, p. 229, nov. 2008.

CALMON, Guilherme. A experiência brasileira na Convenção da Haia sobre sequestro internacional de crianças. EMARF (DVD), 2010.

CARELLA, La Convenzione dell'Aja del 1980 sugli aspetti civili della sottrazione internazionale di minori. Rivista di Diritto Internazionale Privato, jan- abr., 1994.

CONTI. II nuovo regolamento comunitario in materia matrimoniale e di potestà parentale. Rivista di Diritto di Famiglia, jan. 2004.

DOLINGER, Jacob. Direito civil internacional: a família no direito internacional privado. Rio de Janeiro: Renovar, 2003.

ESPÍNOLA, Eduardo. Elementos de Direito Internacional Privado. Rio de Janeiro: Jacinto Ribeiro Santos, 1925.

GAMA E SILVA, Luís Antônio da. As Qualificações em Direito Internacional Privado. São Paulo: RT, 1952.

GEBAUER, Martin. Uniform Law, General Principles na Autonomous Interpretation, 5 Unif., 2000

GONZÁLEZ, Beilfuss Cristina. La aplicación del convenio de la Haya sobre los aspectos civiles de la sustracción internacional de menores en la Republica Argentina: A propósito de la sentencia de la Corte Suprema de Justicia de 14 de junio de 1995. Revista Española de Derecho Internacional. Madrid, v. XLVII, № 2, fev. 1995 
GUIDE TO GOOD PRACTICE UNDER THE HAGUE CONVENTION OF 25 OCTOBER ON THE CIVIL ASPECTS OF INTERNATIONAL CHILD ABDUCTION. Part I - Central Authority Practice, 2003.

MARTINS, Natalia Camba. Subtração Internacional de Crianças - As exceções à obrigação de retorno previstas na Convenção de Haia de 1980 sobre os aspectos civis do sequestro internacional de crianças. Curitiba: Editora CRV, 2013

MAURIQUE, Jorge Antonio. Sequestro Internacional de Crianças: Anotações sobre a Convenção de Haia. Revista Jurídica Consulex. Ano XII, no 284, p. 25, nov. 2008.

MÉRIDA, Carolina Helena Lucas. Sequestro Interparental: o novo direito das crianças. In: Revista Internacional de Direito e Cidadania, no 9, p. 13-14, fev. 2011.

PAIS, Marta Santos. Enfants Deplaces: Comment garantir leur droit a une vie de famille. Documentação e Direito Comparado. Lisboa, no 65-66, jun. 2006.

PEREIRA, Tânia da Silva. O melhor interesse da criança: um debate interdisciplinar. Rio de Janeiro: Renovar, 1999

PEREZ-VERA, Explanatory Report on the 1980 Hague Child Abduction Convention. L'Aja, 1982.

STRENGER, Irineu. Direito Internacional Privado. 3. ed. São Paulo: Editora LTr, 1996.

TIBURCIO, Carmen. A Experiência Brasileira na Convenção da Haia sobre Seqüestro Internacional de Crianças. EMARF(DVD), 2010. 